\title{
СОЦІАЛЬНО-ПСИХОЛОГІЧНІ ОСОБЛИВОСТІ ІНКОРПОРАЦІЇ ПІДЛІТКІВ У СЕРЕДОВИЩЕ ДЕСТРУКТИВНИХ МОЛОДІЖНИХ СУБКУЛЬТУР
}

У статті подано науково-теоретичний огляд вітчизняних та зарубіжних досліджень, присвячених проблемі сочіально-психологічного статусу молодіжсних субкультур як детермінанти формування деструктивної поведінки в молодіжному середовищі. Розглядаються психологічні особливості субкультур як однієї з рушійних сил соиіалізації особистості. Розкрито механізми формування молодіжних субкультур, а також проаналізовано місие молоді у кримінальних субкультурах. Здійснено аналіз соціальних відхилень поведінки особистості, які формуються під впливом молодіжних угруповань, а також аналіз теорії причин виникнення відхилень.

Проаналізовано поняття «молодіжна субкультура», подано коротку характеристику ї основних видів та розглянуто вплив неформальних об'єднань на иінності й моральні норми молоді. Розкрито позитивні та негативні сторони впливу субкультур на культуру української молоді, а також зроблено висновок про зв'язок неформальних угруповань з утворенням адиктивних форм поведінки у молодіжному середовищі. Виокремлено та узагальнено причини, щзо спонукають молодь до пошуку себе в молодіжних об'єднаннях.

Ключові слова: молодіжне середовище, молодіжна субкультура, соиіалізація особистості, передумови десоиіалізаџії, неформальні об'єднання, особливості субкультур.

В статье представлен научно-теоретический обзор отечественных и зарубежных исследований, посвященных проблеме соииально-психологического статуса молодежных субкультур как детерминанты формирования деструктивного поведения в молодежной среде. Рассматриваются психологические особенности субкультур как одной из движущих сил социализачии личности. Раскрыты механизмы формирования молодежных субкультур, а также проанализировано место молодежи в уголовных субкультурах. Осуществлен анализ социальных отклонений поведения личности, которые формируются под влиянием молодежных группировок, а также проведен анализ теории причин возникновения отклонений.

Проанализировано понятие «молодежная субкультура», дана краткая характеристика ее основных видов и рассмотрено влияние неформальных объединений на ценности и нравственные нормы молодежи. Раскрыто положительные и отрицательные стороны воздействия субкультур на культуру украинской молодежи, а также сделан вывод о связи неформальных группировок $c$ образованием аддиктивных форм поведения в молодежной среде. Выделены и обобщены причины, побуждающие молодежь к поиску себя в молодежных объединениях.

Ключевые слова: молодежная среда, молодежная субкультура, сочиализачия личности, предпосылки десочиализации, неформальные объединения, особенности субкультур.

Постановка проблеми. Процеси трансформації, які відбуваються в сучасному українському суспільстві та означають перехід до нової моделі розвитку, супроводжуються глибокою кризою, яка охопила усі сфери суспільства. Руйнування системи духовного самовідтворення суспільства (криза традиційних інститутів соціалізації, ціннісно-нормативна дезінтеграція) ускладнює процес соціальнопсихологічної та культурної адаптації молоді, іï пошуку соціально прийнятних і індивідуально оптимальних форм самореалізації. Соціальна аномія посилює конфліктне протистояння між поколіннями, що відображається кризою соціокультурної ідентичності та руйнуванням духовноморальних основ соціального буття - формують девальвацію морально-ціннісних установок та самореалізації особистості, викликаючи зростання асоціальних і протиправних форм молодіжної активності.

Розширення числа соціально вразливих груп молоді на одному полюсі (в силу відсутності реальних умов для професійного становлення, отримання повноцінної середньої та вищої освіти) i одночасно культивування елітарних - на іншому, викликають зростання індивідуалізму в найбільш гострих проявах, активно породжують деструктивний тип свідомості, формуючи в молоді відчуття соціальної безперспективності, стимулюють асоціальні форми протесту. В умовах трансформації суспільства, що супроводжується безробіттям, деформацією ціннісних орієнтацій, безперспективністю особистісної самореалізації формуються деструктивні поведінкові механізми в молодіжному середовищі. Зміна процесів модифікації, оновлення та трансформації сучасного суспільства в постсучасне відображається у формуванні та функціонуванні підліткових субкультур, оскільки підлітковий вік $\epsilon$ не тільки найбільш важким і складним 3 усіх вікових періодів, але $\mathrm{i}$ 
найвідповідальнішим періодом у становленні особистості тому що, саме в цьому віці закладаються основи моральності, формуються соціальні установки, ціннісні критерії, переконання, ставлення до себе, до людей, до суспільства. У цей час у процесі фізичного, психічного і соціального розвитку разом 3 позитивними досягненнями закономірно виникають негативні утворення і специфічні психологічні та соціальні труднощі. Причому, зараз підлітки, як особлива соціальна і вікова група, зазнали найбільш деструктивних зовнішніх впливів.

Надмірно швидкий розвиток суспільства вимагає орієнтації особистості у всіх сферах життя, неординарного підходу до вирішення проблемних питань, оскільки шаблонна система вже $\epsilon$ застарілою і у меншій мірі ефективною. Усе це зумовлює необхідність творчої участі в них усіх членів суспільства. Особливої уваги потребують завдання формування всебічно та гармонійно розвиненої особистості, здійснення регульованого та цілеспрямованого комплексного впливу з боку усіх суб'єктів соціалізації підлітків.

Аналіз останніх досліджень та публікацій. Проблема дослідження особливостей впливу молодіжної субкультури на особистість у підлітковому віці представлена у дослідженнях сучасних вітчизняних та зарубіжних науковців у галузі психології, педагогіки, правознавства, криміналістики, соціології та культурології. На думку В. Павелківа, диференціація соціально-економічних умов життя породжує розшарування суспільства, що є однією з основних причин фрустрацій юнаків $\mathrm{i}$, як наслідок, обумовлює негативну реакцію і розвиток агресії, як способу захисту своїх ціннісноорієнтаційних установок на життя, спонукає до участі у молодіжних субкультурах як протесту проти суспільних норм і правил [5, с. 295].

Методологічні основи сучасних досліджень детермінації особистісних деструкцій в сучасних наукових теоріях, віднесені до праць авторів теорії аномії (Е. Дюркгейм, Р. Мертон) та концепцій соціалізації (Т. Парсонс). Науковці по-різному трактують основний зміст деструкцій, їхні властивості, специфічні чинники формування, що впливають на афективні, перцептивні, когнітивні, ціннісно-смислові та, власне, поведінкові прояви представників молодіжних субкультур. Специфіка формування та механізми функціонування молодіжних субкультур у соціумі описані в концепціях вітчизняних та зарубіжних вчених. Зокрема, питання еволюції молодіжних субкультур в історичному контексті висвітлюються у роботах I. Альохіна, С. Бондирєвої, І. Колесникової, А. Мудрик, В. Савченко, Є. Федак та ін. Соціокультурні та психолого-педагогічні аспекти формування молодіжних субкультур знаходимо у роботах 3. Абросимова, Є. Баранов, С. Возжаєв, Г. Голіцин, Н. Голубкова, Т. Єгорова, А. Матвєєва та ін.

Процес виникнення молодіжних субкультур трактується як взаємозалежність, з одного боку, невизначеності ціннісної системи, яка властива складним диференційованим групам, а 3 іншого, як породження спектра молодіжних проблем [6]. Осмислення ролі та місця молодіжних субкультур у соціальному просторі та їх вплив на процес соціалізації особистості, залежність формування поведінкового механізму молоді від субкультуральних впливів представлено у дослідженнях В. Букатова, О. Долженко, М. Лукацького, В. Розіна, А. Тутікова.

Г. Андрєєва, С. Максименко, В. Казміренко, Л. Орбан-Лембрик, В. Третьяченко розглядають соціально-психологічну детермінацію поведінки особистості, включеної до простору молодіжної субкультури. Особливості соціально-психологічної інкорпорації до субкультурального простору, зумовленої особливостями ціннісно-смислової сфери підліткового віку (прагнення до інтимноособистісного, стихійно-групового спілкування і самоствердження) представлено у дослідженнях Г. Абрамової, І. Дубровіної, А. Реана, Д. Фельдштейна.

Негативний вплив молодіжної субкультури на особистість описану в працях науковців щодо яких: О. Бандура, А. Басс, З. Берковіц, Дж. Браун, Б. Грушин, Р. Гурова, Л. Жиліна, П. Кауфман, К. Лоренц, М. Мюррей, В. Павелків, К. Річард, Р. Уолтер, 3. Фройд, Н. Фролова, Е. Фромм, М. Шакуров та ін. (виникнення агресії під впливом субкультур); Ю. Александров, Ю. Антонян, І. Башкатов, В. Васильєв, Д. Корецький, Д. Лі, В. Пирожков, Ж. Россі, О. Старков, В. Чалідзе (вплив субкультур на формування девіацій у підлітків).

Проблема формування та функціонування деструктивних субкультур описана в девіантології (О. Змановська, Ю. Клейберг); кримінальній психології (Ю. Антонян, С. Горбатовська, І. Кудрявцев, С. Лебедєв); соціології (Ю. Волков, В. Добреньков, І. Савченко, В. Шаповалов). Особливості трансформації молодіжної субкультури в контексті зближення 3 кримінальною контркультурою розглядали Ш. Бюлер, Р. Бергіус, Е. Хурлок, Р. Муус, Л. Розенмайер, Г. Гризе, С. Ейзенштадт, К. Пржеклавський, Ф. Тенбрук, К. Манхейм. Питаннями профілактики особистісних деструкцій займалися В. Волков, Н. Гусєва, С. Кулаков, Г. Макартичева, Б. Матвєєв, Є. Сидоренко, Е. Федосенко, К. Фопель. 
Незважаючи на високий теоретичний рівень проаналізованих досліджень, важливо констатувати, що проблема профілактики негативного впливу молодіжної субкультури на особистість не вирішена, що зумовлено відсутністю єдиної універсальної системи цінностей і норм, смислів і значень молодіжних субкультур та постійною трансформацією суспільства. В. Загвязинський та Р. Атаханов вважають, що будь-яка освітня програма повинна враховувати соціальну обумовленість і безперервне оновлення цілей, змісту і методів виховання і освіти відповідно до вимог суспільства [3].

Відомості про особливості зміни особистісного розвитку під впливом субкультурального середовища мають переважно інформаційно-масовий характер. Водночас, соціально-психологічний аспект інкорпорації підлітків у середовище деструктивних молодіжних субкультур вивчено недостатньо.

Формулювання цілей статті. Метою даної статті є систематизація соціально-психологічних знань про особливості інкорпорації підлітків у середовище деструктивних молодіжних субкультур. Вивчення негативного впливу субкультури на особистість, детермінант і змісту деструктивної трансформації особистості.

Виклад основного матеріалу дослідження. Науковий інтерес дослідження молодіжних субкультур як соціально-психологічного феномену вперше виник у 40-50-х роках XX століття $\mathrm{i}$ досліджувався, як антипод панівної культури. Американський соціолог Д. Рісман пояснював явище субкультури як культуру групи людей, які навмисно обирають стиль і цінності, що бажані меншістю. Ретельний аналіз явища і поняття субкультури провів британський соціолог Д. Хебдідж, який підкреслював маргінальний характер субкультури і пояснював механізм залучення людей у субкультуральне середовище через протест до суспільства, що зумовлений не задоволенням загальноприйнятими стандартами і цінностями [11].

Під субкультурою розуміється система цінностей, установок, способів поведінки і життєвих стилів, яка притаманна відносно невеликий спільності (групі), просторово і соціально більшою чи меншою мірою відособленим [4]. Подібне трактування феномену субкультури описано О. Сгоровим: «... особлива сфера культури, суверенне цілісне утворення всередині панівної культури, що відрізняється власним ціннісним устроєм, звичаями і нормами» [2].

Наукове поняття «субкультури» $\epsilon$ доволі широким та багатогранним, i водночас, дискусивним. Варіативність поглядів, що зумовлено різноманіттям трактувань феномену субкультури 3 позицій соціокультурних та психолого-педагогічних наук залежно від предмета та методології дослідження, сформували ряд підходів до вивчення і опису цього явища: функціональний (Т. Парсонс), класовий (Д. Доунс, П. Вілліс), гендерний (Б. Худсон, А. Мак Роббі), культурологічний (К. Маннгейм), теорія субкультур (Р. Мертон) тощо.

Першим соціологічним підходом, у рамках якого вчені виявили цікавість до аналізу молодіжних субкультур, став функціоналізм. Крізь призму функціонального підходу розглянутий феномен вивчав Т. Парсонс, який розробив саме поняття «молодіжна субкультура». Т. Парсонс стверджував, що молодіжні субкультури, мають одночасно як прогресивне, так і деструктивне функціональне значення. 3 одного боку, вони руйнують традиційні ціннісні системи, а 3 іншого виступають засобами трансформації застарілої системи, що адаптує ії у відповідність із сучасними тенденціями розвитку, створюють і стверджують нові ціннісні значення [6]. 3. Сікевич вважає, що молодіжна субкультура - це характеристика молодого покоління, якій притаманна цілісна структура - субкультуральне «ядро», що об’єднує молодих людей у формальні і неформальні молодіжні угрупування, яким характерні специфічні норми, цінності, мода і стиль життя. Дослідники феномена субкультури стверджують, що для будь-якої субкультури існує обов'язковий набір характеристик: специфічний стиль життя і поведінки, своєрідні цінності і норми, особливе світосприйняття тощо. Молодіжна субкультура демонструє формування опозиційного (не обов'язково ворожого) світогляду щодо встановлених загальноприйнятих норм і цінностей суспільства. Кожна субкультура має специфічні особливості, але при цьому є складовою частиною базової культури, яка виступає інноваційною сферою і схильна до змін.

Синтезуючи наукові підходи дослідження субкультури, можна констатувати, що молодіжна субкультура - це відносно самостійна, стихійна структура всередині загальної соціокультурної системи, яка включає в себе специфічний набір соціально-психологічних характеристик: якості, потреби і мотиви, цілі та інтереси, норми і ціннісні орієнтації, що впливають на стиль життя i мислення, певних реальних і номінальних груп людей.

Д. Парфенюк вважає, що передумовами виникнення і формування субкультури є економічні, політичні і соціальні кризи, установлення демократичних форм правління державою, впровадження нових технологій, що дали можливість якісно поліпшити життєвий рівень і інформаційне 
забезпечення [7, с.10]. В. Лабунська стверджує, що системна криза, яка призвела до зміни соціальних орієнтирів і переоцінці традиційних цінностей, та трансформація суспільства - фактори зниження толерантності до себе і до світу, що є причиною зниження особистої відповідальності [8].

В умовах соціальної кризи найбільше піддаються травматичним впливам та знеціненням ідеалів незахищені суспільні категорії, серед яких особливо вразливими є підлітки, оскільки підлітковий період розвитку особистості представлений складними й суперечливими змінами, які стосуються процесу формування, самовизначення і самоствердження особистості, відбувається перехід від дитинства до юності, від незрілості до зрілості. Підлітки найбільш чутливі до соціальних і психологічних стресів. Саме в цьому віці спостерігається різке зростання кількості конфліктних, недисциплінованих, які не вміють володіти собою підлітків. Особистісний розвиток у підлітковому віці характеризується підвищеною емоційністю, інтенсивним розвитком самосвідомості, появою почуття дорослості, прагненням до самовизначення, самоствердження i спрямованістю на спілкування з однолітками. Центральним новоутворення у підлітковому віці є настання статевої зрілості, яка формує певні психологічні зрушення: поява потягу до протилежної статі, агресивність (часто невмотивована), схильність до необдуманого ризику і невміння оцінити ступінь небезпеки, підкреслене прагнення до незалежності і самостійності (реакція емансипації). Сутністю підліткового віку Л. Виготський вважав розбіжність трьох точок дозрівання: «Статеве дозрівання починається і завершується раніше, ніж наступає закінчення загального фізіологічного розвитку підлітка, і раніше, ніж підліток досягає остаточного соціально-культурного формування», вказуючи на типові риси підлітка: виникнення інтроспекції, що веде до самоаналізу; поява особливого інтересу до своїх переживань, незадоволення зовнішнім світом, відхід у себе, поява почуття винятковості, прагнення до самоствердження, протиставлення себе оточуючим, конфлікти з ними [1]. У підлітковому віці дитина знаходиться під впливом щонайменше двох суперечливих тенденцій: формування особистісних властивостей та установлення міжособистісних контактів з іншими людьми.

Одна з основних проблем молоді - проблема спілкування з однолітками, оскільки референтна соціальна група, у якій перебуває людина, багато в чому визначає поведінку, діяльність, а в подальшому впливає на розвиток особистісних якостей і соціальних настанов індивіда. Головною функцій міжособистісного спілкування у референтній групі $\epsilon$ вироблення прийнятних рішень, усунення протиріч, що породжують ворожнечу і непримиренність, досягнення спонтанною групою статусу конвенційного об’єднання на основі спільних домовленостей та взаємних поступок. Спілкування 3 ровесниками є своєрідним випробуванням себе у сфері особистісної, зокрема специфічної моральної проблематики. Л. Столяренко вважає, що розвиток самосвідомості як центрального новоутворення підліткового віку стає можливим і цілком залежить від культурного змісту середовища [9]. 3 одного боку, підлітковий вік - це час індивідуалізації, відкриття й утвердження «внутрішньої позиції», а 3 іншого - час соціалізації, входження у світ людської культури й соціальних цінностей, інтенсивного формування та соціальне «Я». Труднощі соціалізації підлітків зумовлені особливостями соціального середовища та індивідуальною здатністю і готовністю підлітка адаптуватися до умов, у якому відбувається процес соціалізації.

Молодіжна субкультура реалізовує два основні механізми соціалізації підлітків інтеріоризацію (засвоєння та привласнення індивідом знань, норм, цінностей певного суспільства, оволодіння соціальними відносинами, перетворення їх у надбання внутрішнього світу особистості) та екстеріоризацію (активне відтворення індивідом у своїй діяльності засвоєного соціального досвіду). Т. Парсонс наголошував на визначальній ролі молодіжної субкультури у процесі соціалізації підлітка, через соціальний супровід індивіда від моменту його виходу з сім'ї батьків і до створення сім'ї власної [6]. У середовищі молодіжної субкультури підліток реалізаціє потребу ескапізму та «втечі від реальності», а отже, протиставляє себе панівній, офіційній культурі. Перебуваючи в субкультуральній групі однолітків, як в мікросоціумі зі своєю культурою, підліток переймає патерни субкультуральної поведінки, відповідні цінності, норми і способи мислення.

Основними причинами інкорпорації підлітків в молодіжну субкультуру є: реалізація потреби в спілкуванні з однолітками, реакція групування, задоволення почуття приналежності, вирішення вікової кризу ідентичності (Е. Еріксон), відчуження від традиційних інститутів соціалізації (школи, сім’ї), статусна незадоволеність, пошук альтернативної групи (В. Кудрявцев, К. Павлова). Будучи суб'єктом не тільки спілкування, а й навчальної діяльності, підліток характеризується тенденцією до утвердження своєї позиції суб'єктної винятковості, індивідуальності [9]. Потрапляючи в субкультуральне середовище, підлітки втрачають зв'язок з суспільством, проходячи процес соціалізації в своїй контркультурній групі (формування стилю поведінки і спосіб життя, що суперечать загальноприйнятим орієнтирів), що ускладнює адаптацію «неформала» в соціумі, оскільки діяльність підлітка спрямована на реалізацію потреб своїх однодумців. Нестійкість 
ціннісних орієнтацій і недостатньо високий рівень правосвідомості молоді створюють передумови до асоціальної та агресивної поведінки. Негативні тенденції підкріплюються посиленням росту молодіжних субкультур, прояви яких часто мають жорсткий і агресивний характер. В учасників неформальних груп, що належать до подібних субкультур, більш виражені особливості особистості, що підвищують ризик девіантної поведінки. Так сучасні молодіжні субкультури продукують ризики, пов'язані з дедалі більшим зростанням агресивності та насильства серед її суб'єктів [5, с. 297].

Аналізуючи деструктивний потенціал молодіжної субкультури, слід зазначити, що певна ступінь ризику закладена в «конфліктності поколінь» (М. Мід, Т. Парсонс) - молодь безапеляційно піддає переосмисленню погляди і ціннісні установки старшого покоління, яке, на опозиційну думку молоді, не визнає за ними статусу дорослої людини, що перешкоджає розвитку і засвоєнню підлітком нових соціальних ролей. У класифікації М. Брейка більшість субкультур молоді - це «колективні девіації», причому характер та рівень відхилення від соціально-культурної та правової норми в них різний: це делінквентна молодь, яка скоює злочини, політично девіантно-активна молодь, що схильна до політичних протистоянь, соціокультурні бунтівники з артистичних тусовок [10]. Д. Хебдідж акцентував увагу на активному виборі індивідом відповідної молодіжної субкультури, що характеризується осмисленням відповідальності за прийняття правил, стилю поведінки, норм i цінностей неформального угрупування [11].

Вплив ряду молодіжних субкультур приховує у собі соціальні небезпеки, так як одні субкультури транслюють ідеї екстремізму, расової та національної дискримінації, невмотивованої агресії до інших культур і осіб (скінхеди, екстремістські політизовані субкультури лівого і правого напрямів, футбольні хулігани), інші - проповідують кримінальний спосіб життя (гопники, панки), треті - пропагують вживання психоактивнихта наркотичних речовин (рейвери, растамани). Перелічені субкультури формують у підлітків неадекватне сприйняття реальності, знецінення моральних і етичних норм та правил, спричиняють десоціалізацію особистості, розвивають постійну потребу у застосуванні агресії та прояву девіантної, а у деяких випадках і адиктивної поведінки.

У міру поглиблення групової ідентифікації зростають також тиск конформізму та деіндивідуалізація. Найбільш поширеним результатом стає соціальне «зараження» - підживлення групою збудження, втрата «стримуючих» центрів і поляризація. Особистість підлітка формується під впливом оточуючої навколишньої реальності. Особливо важливу роль мають малі референтні групи, в яких особистість взаємодіє з іншими людьми. До таких груп відносяться і субкультури, оскільки для учасника групи $є$ важливим наслідування традицій, норм та правил поведінки, які встановлені в даному середовищі.

Висновки 3 даного дослідження і перспективи подальших розвідок. Найважливішими соціально-психологічними особливостями інкорпорації підлітків у середовище деструктивних молодіжних субкультур є підлітковий період невизначеності, конфліктність поведінки, протест проти суспільства, криза соціальної ідентичності. Молодіжна субкультура, яка являється частиною загальної культури суспільства і $є$ системою норм, цінностей, поглядів, переконань, принципів молоді, має два прояви свого впливу на осіб підліткового віку. Позитивним аспектом перебування у нефомальному угрупуванні $є$ те, що субкультура, як своєрідний компенсуючий механізм, знижує тиск масової, глобальної культури на особистість підлітка та послаблює кризу ідентичності. Проте підліток-неформал ізолюється від соціуму, розвивається у просторі угрупування, беззаперечно приймає ідеї та цінності субкультури, що формує у нього асоціальні поведінкові конструкції та знецінення власної особистості.

Перспектива подальшого дослідження проблеми полягає в грунтовному вивченні особливостей становлення та функціонування молодіжних субкультур, дослідженні особливостей формування та прояву особистісних деструкцій підлітків у середовищі молодіжних субкультур, розробці психолого-педагогічної моделі розвитку соціальної активності особистості та формування життєвої позиції у підлітковому віці.

\section{Список використаних джерел}

1. Выготский Л. С. Психология развития человека / Л. С. Выготский. - М. : Смысл, 2005. $1136 \mathrm{c}$.

2. Егоров А. Ю. Расстройства поведения у подростков: клинико-психологические аспекты / А. Ю. Егоров. - СПб. : Речь, 2005. - 435 с.

3. Загвязинский В. И. Методология и методы психолого-педагогического исследования : учеб. пособ. для студентов высш. учеб. заведений / В. И. Загвязинский, Р. Атаханов. - М. : Издат. центр «Академия», 2006. - $208 \mathrm{c.}$ 
4. Луков В. А. Молодежные субкультуры в современной России / В. А. Луков // Гуманитарное знание в XXI веке. - М. : Изд-во Нац. ин-та бизнеса, 2006. - С. 478-505.

5. Павелків В. Р. Агресія як феномен сучасності в системах молодіжних субкультур / В. Р. Павелків // Проблеми сучасної психології : зб. наук. пр. Кам'янець-Поділ. нац. ун-ту ім. Івана Огієнка, Ін-ту психології ім. Г. С. Костюка НАПН України. - Кам’янець-Подільський : Аксіома, 2016. - Вип. 31. - С. 293-303.

6. Парсонс Т. О социальных системах / Т. Парсонс. - М. : Акад. Проспект, 2002. - 832 с.

7. Парфенюк Д. В. Социально-психологическая направленность представителей молодежных субкультур : автореф. дис. ... канд. психол. наук : 19.00.05 - Социальная психология / Д. В. Парфенюк. - М., 2011. - 24 с.

8. Социальная психология личности в вопросах и ответах : учеб. пособ. / под ред. В. А. Лабунской. - М. : Гардарики, 2004. - 397 с.

9. Столяренко Л. Д. Педагогическая психология / Л. Д. Столяренко. - Ростов н/Д : Феникс, 2003. $-544 \mathrm{c}$.

10. Brake M. The Sociology of Youth Culture and Youth Subcultures (Routledge Revivals): Sex and Drugs and Rock 'n' Roll? / M. Brake. - London : Routledge, 2014. - 216 p.

11. Hebdige D. Subculture: The meaning of the style / D. Hebdige. - London and New York : Taylor \& Francis e-Library, 2002. - 206 p.

\section{References}

1. Vygotskij L. S. Psihologija razvitija cheloveka / L. S. Vygotskij. - M. : Smysl, 2005. - 1136 s.

2. Egorov A. Ju. Rasstrojstva povedenija u podrostkov: kliniko-psihologicheskie aspekty / A. Ju. Egorov. - SPb. : Rech', 2005. - 435 s.

3. Zagvjazinskij V. I. Metodologija i metody psihologo-pedagogicheskogo issledovanija : ucheb. posob. dlja studentov vyssh. ucheb. zavedenij / V. I. Zagvjazinskij, R. Atahanov. - M. : Izdat. centr «Akademija», 2006. - 208 s.

4. Lukov V. A. Molodezhnye subkul'tury v sovremennoj Rossii / V. A. Lukov // Gumanitarnoe znanie v XXI veke. - M. : Izd-vo Nac. in-ta biznesa, 2006. - S. 478-505.

5. Pavelkiv V. R. Agresija jak fenomen suchasnosti v sistemah molodizhnih subkul'tur / V. R. Pavelkiv // Problemi suchasnoï psihologiï : zb. nauk. pr. Kam'janec'-Podil. nats. un-tu im. Ivana Ogiєnka, Intu psihologiï im. G. S. Kostjuka NAPN Ukraïni. - Kam'janec'-Podil's'kij : Aksioma, 2016. - Vip. 31. - S. 293-303.

6. Parsons T. O social'nyh sistemah / T. Parsons. - M. : Akad. Prospekt, 2002. - $832 \mathrm{~s}$

7. Parfenjuk D. V. Social'no-psihologicheskaja napravlennost' predstavitelej molodezhnyh subkul'tur : avtoref. dis. ... kand. psih. nauk : 19.00.05 - Social'naja psihologija / D. V. Parfenjuk. - M., 2011. $-24 \mathrm{~s}$.

8. Social'naja psihologija lichnosti $\mathrm{v}$ voprosah i otvetah : ucheb. posob. / pod red. V. A. Labunskoj. - M. : Gardariki, 2004. - 397 s.

9. Stoljarenko L. D. Pedagogicheskaja psihologija / L. D. Stoljarenko. - Rostov n/D : Feniks, 2003. $-544 \mathrm{~s}$.

10. Brake M. The Sociology of Youth Culture and Youth Subcultures (Routledge Revivals): Sex and Drugs and Rock 'n' Roll? / M. Brake. - London : Routledge, 2014. - 216 p.

11. Hebdige D. Subculture: The meaning of the style / D. Hebdige. - London and New York : Taylor \& Francis e-Library, 2002. - 206 p.

\section{V.M. Panasiuk SOCIO-PSYCHOLOGICAL SPECIFICS OF TEENAGER INCORPORATION IN THE ENVIRONMENT OF DESTRUCTIVE YOUTH SUBCULTURES}

The paper presents a theoretical review of the scientific and national and international research on the problem of socio-psychological status of youth subcultures as determinants of formation of destructive behavior among youth. We consider the psychological characteristics of subcultures as one of the driving forces of socialization. The mechanisms of formation of youth subcultures, as well as analyzes the place of youth in the criminal subculture. The analysis of the social behavior of the individual deviations, which are formed under the influence of youth gangs, as well as analysis of the theory of the causes of deviations.

Analyzed the concept of "youth subculture», presented a brief description of its main species and the effect of informal associations values and moral standards of young people. Discloses the positive and negative aspects of the impact of subcultures on the culture of the Ukrainian youth, as well as the conclusion of the connection with the formation of informal groups of addictive behaviors among youth. 

associations.

Identifed and summarized the causes which impel young people to find themselves in youth

Keywords: youth, youth subculture, socialization of personality, background desocialization, informal associations, particularly subcultures. 